\title{
Assessment of Microbiological Quality of Air Environment Around Waste Dumpsites Within Keffi Metropolis in Northern Nigeria
}

\author{
Obiekezie Smart Obumneme ${ }^{1, ~ *, ~ E k e l e m e ~ I k e ~ K e n n e t h ~}{ }^{1}$, Adamu Muktar Owuna ${ }^{1}$, \\ Gnimintakpa M'bouyowe Joseph ${ }^{2}$, Onalo Cornelius and Sabo ${ }^{1}$, Abdullahi Ado ${ }^{3}$ \\ ${ }^{1}$ Department of Microbiology, Nasarawa State University, Keffi, Nigeria \\ ${ }^{2}$ Department of Biochemistry and Molecular Biology, Federal University Dutsinma, Dutsin-ma, Nigeria \\ ${ }^{3}$ Department of Biological Sciences, Sa'adatu Rimi College of Education, Nigeria
}

Email address:

drsmartobiekezie@yahoo.com (O.S. Obumneme)

${ }^{*}$ Corresponding author

\section{To cite this article:}

Obiekezie Smart Obumneme, Ekeleme Ike Kenneth, Adamu Muktar Owuna, Gnimintakpa M'bouyowe Joseph, Onalo Cornelius and Sabo, Abdullahi Ado. Assessment of Microbiological Quality of Air Environment Around Waste Dumpsites Within Keffi Metropolis in Northern Nigeria. American Journal of Biological and Environmental Statistics. Special Issue: Microbes, Man and Environmental Sustainability. Vol. 5, No. 4, 2019, pp. 78-84. doi: 10.11648/j.ajbes.20190504.13

Received: November 30, 2019; Accepted: December 16, 2019; Published: December 24, 2019

\begin{abstract}
This study is to assess the microbiological quality and public health hazard associated with the air environment around waste dumpsites in Keffi, metropolis Nigeria was conducted. A total of 25 samples were collected from five different waste dumpsites around five different locations within the metropolis (Angwan Lambu, Keffi Main market, University Main campus and Nasarawa Road). Preliminary cultural, morphological, biochemical characteristics of the isolates revealed the following isolates, Escherichia coli, Pseudomonas aeruginosa, Staphylococcus aureus, Proteus vulgaris, Bacillus spp, Micrococcus spp., Aspergillus niger, Alternaria spp., Penicillum spp., Mucor spp., Fusarium spp., Rhizopus stolonifer and Candida spp. The total bacterial counts from the air environments of these waste dumpsites ranged between 2.2-7.4 x 10 $\mathrm{cfu} / \mathrm{m}^{3}$, while the total fungal counts ranged between 1.4-4.4 × $10^{1} \mathrm{cfu} / \mathrm{m}^{3}$. The susceptibility of the bacterial isolates against commonly used antibiotics tested showed varying degree of susceptibility and it is in the following decreasing order; Proteus vulgaris $(93.3 \%)>$ Staphylococcus aureus $(55.6 \%)>$ Micrococcus spp. $(43.3 \%)>$ Pseudomonas aeruginosa $(42.8 \%)>$ Bacillus spp. $(41.2 \%)>$ Escherichia coli $(30.8 \%)$. Health risk assessment indicates the presence of pathogenic bacteria and moulds with serious health risk to human within the environment due to the possibility of cross contamination of foods sold in the open. Consequently, there is the need to periodically monitor the number of microorganisms within the air of these environments using the established threshold stipulated for microbial concentrations in air.
\end{abstract}

Keywords: Microbiological, Air, Waste Dumpsites, Antibiotic, Keffi, Nigeria

\section{Introduction}

Waste generation by man started since the beginning of civilization as a consequence of human activities, involving the production of goods and services and the consumption of natural resources. Dumpsite is a piece of land where waste materials are disposed. Waste materials could be garbage, rubbish, yard waste, toxic waste and domestic refuse [1]. Municipal solid waste dump areas commonly referred to as waste dumpsites constitute environmental and public health hazards all over the world [2]. More so, human activities such as sewage treatment, plants and animal rendering, fermentation processes and agricultural activities do emit microorganisms into the air [3-6].

Air serves as a mode of transport for the dispersal of bioaerosols (particles of biological origin e.g. bacteria, fungi, pollen, viruses that are important constituents of the atmosphere and could possess the potential to cause a variety of diseases in humans and animals). The composition and 
concentration of the microorganisms comprising the bioaerosols vary with source and their dispersal in air [7]. In the indoor air environment for instance, most of the air pollution comes from sources inside the building itself, hair spray, perfume, room deodorizer, paints, thinners, home appliances, photo copiers, printers, computers, and air purifiers [8]. The use of disinfectants (linear alkyl benzene sulfonates) and fatty acid salts (soap) in cleaning agents (rug shampoo) can cause enhanced eye and airway irritation [9, 10].

The survival of microorganisms in air varies, though generally, fungal spores, enteric viruses and amoebic cysts are somewhat resistant to environmental stresses encountered during transport through air. Bacteria and algae are more susceptible, although bacterial endospores for example spores of Bacillus spp. are quite resistant. In recent years, outdoor air quality has become an important issue, because of industrialization [11]. Microorganisms present in the air originate from soil, plants, water and dispersed by dust. However, spore-forming bacteria and fungi are able to survive in bioaerosols and stay viable for a long time in the air [7].

Several studies have been conducted in order to examine the health and environmental effects arising from waste dumps. Such studies showed that a link exists between the two [12]. The conclusion from this and other studies has led to an increasing interest of researchers in the study relating to environmental pollution as well as its effects on plants and animals. Few of these studies examined the environmental and health implications of solid waste disposal to people living in close proximity of wastes dumpsites [13, 14]. Consequently, this study is aimed to determine the microbiological quality of the air environment around waste dumpiste within Keffi Metropolis in Northern Nigeria highlighting its implications to public health.

\section{Materials and Methods}

\section{Study Area}

This work was carried out in Keffi, Nasarawa State. Keffi is geographically situated on a latitude $8^{\circ} 50^{\prime} \mathrm{N}$ and longitude $7^{\circ} 52^{\prime} \mathrm{E}$. Keffi town is about $850 \mathrm{~m}$ above sea level and it is the North-West of Lafia, the state capital. It is $53 \mathrm{~km}$ away from Abuja Federal Capital of Nigeria in the Guinea Savannah region of Nigeria [15].

Sample Collection

The air samples were collected from five (5) different waste dump sites at Angwan Lambu, Main Market, Main Campus, Pyanku Campus and Nasarawa Road all within Keffi metropolis using the plate sedimentation methods as earlier described by Makut et al. [6] and Udo-Ibiam et al. [16]. Petri dishes containing culture media suitable for bacteria and fungi growth were used as sampling surfaces. Trypticase Soy Agar (TSA) supplemented with cyclohexamide (which inhibits growth of fungi) was used for the determination of the total number of bacteria, while Malt Extract Agar (MEA) supplemented with chloramphenicol (which inhibits the growth of bacteria) was used for the determination of the total number of fungi [17]. The plates were set up at a height representative of the normal human breathing zone, five feet, $150 \mathrm{~cm}, 180 \mathrm{~cm}$ above ground level Udo-Ibiam et al., [16]. Thereafter, plates in triplicates for each type of culture medium were exposed to air in each of the five waste dumpsites for at least 30 minutes in order to allow air microorganisms to settle gravitationally directly on the media surfaces of the plate and transported immediately to the laboratory for incubation analyses.

Isolation and Identification of Microorganisms

Trypticase Soy Agar (TSA) plates were incubated for 48 hrs at $37^{\circ} \mathrm{C}$, while the plates with Malt Extract Agar (MEA) were incubated at $30^{\circ} \mathrm{C}$ for 3-7 days. The total number of colony forming units were enumerated and expressed as colony forming units per cubic meter of air $\left(\mathrm{CFU} / \mathrm{m}^{3}\right)$ [18]. Identification of the bacterial colonies was based on the method of Holt [19]. The bacterial isolates were identified through cultural, morphological and biochemical tests. Identification of the fungal isolates was carried out using standard methods based on macroscopic and microscopic features as described by Cheesbrough [20]. Briefly, wet mounts of the pure culture were prepared and mounted on lacto-phenol cotton blue on a clean slide containing a drop of methanol. Characteristic features such as mycelia, conidia, and sporangia of the fungi were then observed under $\times 10$ and $\times 40$ objectives of the light microscope and compared with an identification chart (atlas) of fungi.

Antibiotic Susceptibility Test

The bacterial isolates were tested for antimicrobial susceptibility using the Kirby-Bauer agar disk diffusion method as described by CLSI [21]. A suspension of each isolate was prepared in peptone water to match 0.5 McFarland turbidity standards in order to standardize the inoculum. The standardized inoculum of each isolate were then inoculated in triplicates onto the surfaces of plain Mueller-Hinton agar plates and Septrin $(30 \mu \mathrm{g})$, Chloramphenicol $(30 \mu \mathrm{g})$, Sparfloxacin $(5 \mu \mathrm{g})$, Amoxicillin (30 $\mu \mathrm{g})$, Ciprofloxacin $(5 \mu \mathrm{g})$ Augmentin $(30 \mu \mathrm{g})$, Gentamycin $(10 \mu \mathrm{g})$, Perfloxacin $(10 \mu \mathrm{g})$, Erythromycin $(15 \mu \mathrm{g})$ and Streptomycin $(10 \mu \mathrm{g})$ discs were placed aseptically and incubated at $37^{\circ} \mathrm{C}$ for $24 \mathrm{~h}$; after which the zones of inhibition were measured and compared with the standards of the Clinical and Laboratory Standards Institute guidelines [21].

\section{Results}

A study to determine the microbiological quality of the air environment around waste dumpsites in Keffi was conducted. A total of 25 samples were collected from five different waste areas around five different locations within the metropolis viz; Angwan Lambu, Keffi Main Market, University Main Campus, Pyanku Campus and Nasarawa Road. Preliminary cultural, morphological and biochemical characteristics of the bacterial isolates revealed the following species, Escherichia coli, Pseudomonas aeruginosa, Staphylococcus aureus, Proteus vulgaris, Bacillus spp. and Micrococcus spp. (Table 1). Similarly, the colonial, 
microscopic and macroscopic features of the fungal isolates revealed the following species, Aspergillus flavus, Aspergillus niger, Alternaria spp., Penicillium spp., Mucor spp., Fusarium spp., Rhizopus stolonifer and Candida spp. (Table 2).

The total bacterial count of the sampled air environments indicate that the highest bacterial count $\left(7.4 \times 10^{1} \mathrm{cfu} / \mathrm{m}^{3}\right)$ was around the waste dumpsite at Nasarawa Road, followed by $\left(6.2 \times 10^{1} \mathrm{cfu} / \mathrm{m}^{3}\right)$ recorded around Main Market waste dumpsite, while the total bacterial counts of $3.8 \times 10^{1} \mathrm{cfu} / \mathrm{m}^{3}$, $3.4 \times 10^{1} \mathrm{cfu} / \mathrm{m}^{3}$ and $2.2 \times 10^{1} \mathrm{cfu} / \mathrm{m}^{3}$ were recorded at the waste dumpsites at Angwan Lambu, Pyanku Campus and the University Main Campus respectively. Similarly, the fungal counts recorded at the studied air environments are in the following decreasing order; Nasarawa Road $\left(4.4 \times 10^{1}\right.$ $\left.\mathrm{cfu} / \mathrm{m}^{3}\right)$, Pyanku Campus $\left(2.6 \times 10^{1} \mathrm{cfu} / \mathrm{m}^{3}\right)$, Main Market $\left(2.4 \times 10^{1} \mathrm{cfu} / \mathrm{m}^{3}\right)$, Angwan Lambu $\left(1.8 \times 10^{1} \mathrm{cfu} / \mathrm{m}^{3}\right)$, while the least fungal counts were recorded around waste dumpsite at the Main Campus $\left(1.4 \times 10^{1} \mathrm{cfu} / \mathrm{m}^{3}\right)$ (Table 3$)$.

The frequency of occurrence of the bacterial isolates indicates that Pseudomonas aeruginosa and Bacillus spp. with an isolation rate of $56.0 \%$ each are the commonest bacterial isolates, followed closely by Staphylococcus aureus and Micrococcus spp. $(40.0 \%$ each), Escherichia coli (36.0\%), Salmonella spp. (28.0\%), while the least occurring bacterial isolate is Proteus vulgaris (20.0\%) (Table 4).

Also, the rate of isolation of the fungal species showed fungi with aseptate hyphae to be the most occurring fungal species; with, Penicillium spp. and Aspergillus niger being the most isolated (36.0\% each), followed closely by Candida spp. and Aspergillus flavus $(32.0 \%$ each). The isolation frequency of the other fungal species were Mucor spp. (28.0\%), Fusarium spp. (20.0\%), Alternaria spp. (20.0\%) and Rhizopus stolonifer (12.0\%) (Table 5).

The antibiotic susceptibility of the bacterial isolates from the air environment around waste dumpsites displayed varying degree of susceptibility as reported in Table 6 . Escherichia coli were found to be susceptible to Chloramphenicol (88.8\%), Augmentin and gentamicin (77.8\%) and Sparfloxacin (55.5\%), but displayed various level of resistant to the other antibiotics tested and even $100 \%$ resistant to Amoxicillin. Pseudomonas aeruginosa was susceptible to Augmentin and Chloramphenicol (71.4\%), Gentamicin (64.3\%) and Co-trimoxazole (57.1\%) but were resistant to the other antibiotics screened.
Similarly, Salmonella spp. exhibited 100\% susceptibility to chloramphenicol, $85.7 \%$ susceptibility to Augmentin and Gentamycin and $71.4 \%$ susceptibility to Amoxicillin. They however, showed low susceptibility to the other antibiotics screened and were all (100\%) resistance to Ofloxacin and Septrin. In the same vein, Staphylococcus aureus was $60.0 \%$ susceptible each to Augmentin, Gentamicin, Septrin, Cotrimoxazole and chloramphenicol but showed resistance to the other antibiotics tested.

Nonetheless, Proteus vulgaris was susceptible to majority of the antibiotics tested, it was found to be highly susceptible to Gentamicin and perfloxacin $(80.0 \%)$. The bacterium was also susceptible to the following antibiotics; augmentin $(60.0 \%)$, ofloxacin $(60.0 \%)$, Septrin $(60.0 \%)$ and chloramphenicol (60.0\%); they were intermediately susceptible to Amoxicillin and Sparfloxacin (40.0\% each), but showed $100 \%$ resistance to co-trimoxazole

Bacillus spp. on the other hand was found to be susceptible to Gentamicin (64.3\%), Augmentin and Chloramphenicol $(57.1 \%$ each). Its susceptibility was low for the other antibiotics as follows; Sparfloxacin, Co-trimoxazole, Septrin and Amoxicillin (28.6\% each), Ofloxacin (35.7\%) and Perfloxacin (42.8\%) Interestingly, Micrococcus spp. been amongst the most common bacterial contaminants of the air environment as observed in this present study was highly susceptible to 3 of the 10 antibiotics tested, Gentamicin (90.0\%), Augmentin and Perfloxacin (70.0\% each), and displayed intermediate degree of susceptibility to Chloramphenicol $(50.0 \%)$ only. Nevertheless, the bacterium was very low susceptibility to co-trimoxazole (10\%) Ofloxacin and Septrin (20.0\%), Amoxicillin and Sparfloxacin (30.0\% each).

Generally, the degree of susceptibility of the 7 bacterial isolates against the 9 antibiotics screened showed that Proteus vulgaris, with $93.3 \%$ susceptibility to all the antibiotics screened is the most susceptible of the bacteria isolated from the air environments. The degree of susceptibility of the other bacterial isolates against the antibiotics screened-are as follows; Staphylococcus aureus (55.6\%) $>$ Salmonella spp. (47.6\%)> Micrococcus spp. $(43.3 \%)>$ Pseudomonas aeruginosa $(42.8 \%)>$ Bacillus spp. (41.2\%), while Escherichia coli with an overall average susceptibility of $30.8 \%$ was the least susceptible isolate to all the antibiotics screened.

Table 1. Cultural, morphological and biochemical characteristics of bacterial isolates from waste dumpsites air environment in Keffi and their probable identity.

\begin{tabular}{|c|c|c|c|c|c|c|c|c|c|c|}
\hline \multicolumn{3}{|c|}{ Cultural \& Morphological Characteristics } & \multirow{2}{*}{$\begin{array}{l}\text { Gram } \\
\text { Staining }\end{array}$} & \multicolumn{6}{|c|}{ Biochemical Tests } & \multirow{2}{*}{ Probable isolates } \\
\hline Shape & Size & Pigmentation & & CAT & IN & VP & MR & $\mathbf{O X}$ & CT & \\
\hline Slightly curved rod & $1 \mathrm{~mm}$ & Greenish on EMB pink on MAC & - & + & + & - & + & - & - & Escherichia coli \\
\hline Curved rod & $0.3 \mathrm{~mm}$ & Whitish on NA colourless on MAC & - & + & - & - & - & + & + & Pseudomonas aeruginosa \\
\hline Cocci in clusters & $0.4 \mathrm{~mm}$ & Golden yellow on MSA & + & + & - & - & - & - & + & Staphylococcus aureus \\
\hline Irregular pair of rods & $1 \mathrm{~mm}$ & Colourless on MAC & - & + & + & - & + & - & - & Proteus vulgaris \\
\hline Smooth rod & $2 \mathrm{~mm}$ & Whitish on NA & + & + & - & - & - & - & + & Bacillus spp. \\
\hline Cocci in pairs & $0.5 \mathrm{~mm}$ & $\begin{array}{l}\text { Bright Yellow colonies with red } \\
\text { spots on NA }\end{array}$ & + & + & - & - & - & + & + & Micrococcus spp. \\
\hline
\end{tabular}

Where: $\mathrm{CAT}=$ Catalase, $\mathrm{IN}=$ Indole, $\mathrm{MR}=$ Methyl red, $\mathrm{OX}=$ Oxidase, $\mathrm{VP}=$ Voges Proskauer, $\mathrm{CT}=\mathrm{Citrate}$ Utilization Test,$+=$ positive,$-=$ negative, EMB $=$ Eosine Methylene Blue agar, NA= Nutrient Agar, MAC = MacConkey agar, MSA= Manitol Salt Agar. 
Obiekezie Smart Obumneme et al:: Assessment of Microbiological Quality of Air Environment Around Waste Dumpsites Within Keffi Metropolis in Northern Nigeria

Table 2. Cultural and morphological characteristic of fungal Isolates from waste dumpsites' air environment in Keffi and their probable identity.

\begin{tabular}{llll}
\hline Mycelia Colour & Type of Structure & Spore Hyphae & Spore Appearance \\
\hline Green & Aseptate & Conidiophores & Smooth conidiophores \\
Black & Aseptate & Conidiophores & Condia globose \\
Black & Septate & Meiospores & Macroconidia Aspergillus niger \\
Bluish-Green & Aseptate & Conidiophores & Branched Alternaria spp. \\
Black & Aseptate & Sporangiosphore & Smooth, sporangium \\
Yellowish or orange & Septate & Conidiophores & Macroconidia Microconidia Fusarium spp. \\
Black & Aseptate & Sporangiospores & Large sporangium \\
Creamy white & Aseptate & Conidiophores & Large sporangium \\
\hline
\end{tabular}

Table 3. Total Bacterial and Fungal counts in the Air Environment around Waste dumpsite in Keffi Metropolis $\left(\times 10^{1}\right.$ cfu $\left./ \mathrm{m}^{3}\right)$.

\begin{tabular}{lllll}
\hline \multirow{2}{*}{ Sampling Location } & Total Bacterial & S.D & Total Fungal \\
\cline { 2 - 5 } & Counts & & Counts \\
\hline Angwan Lambu & 3.8 & \pm 0.2 & 1.8 & \pm 2.0 \\
Main Market & 6.2 & \pm 0.6 & 2.4 & 1.4 \\
Main Campus & 2.2 & \pm 1.4 & 2.6 & \pm 0.003 \\
Pyanku Campus & 3.4 & \pm 0.4 & 4.4 & \pm 0.003 \\
Nasarawa Road & 7.4 & \pm 1.9 & \pm 0.9 \\
\hline
\end{tabular}

$\mathrm{SD}=$ Standard Deviation

Table 4. Isolation rates of the Bacterial isolates (\%) in the Air Environment around Waste dumpsites in Keffi Metropolis.

\begin{tabular}{|c|c|c|c|c|c|c|}
\hline Locations (n) & E. $\operatorname{coli}(\%)$ & Pseud. aerug. (\%) & $\begin{array}{l}\text { Staph. Aureus } \\
(\%)\end{array}$ & $\begin{array}{l}\text { Proteus vulgaris } \\
(\%)\end{array}$ & Bacillus spp. (\%) & $\begin{array}{l}\text { Micrococcus spp. } \\
(\%)\end{array}$ \\
\hline Angwan Lambu (5) & $2(40.0)$ & $2(40.0)$ & $1(20.0)$ & $1(20.0)$ & $2(40.0)$ & $2(40.0)$ \\
\hline Main Market (5) & $3(60.0)$ & $4(80.0)$ & $3(60.0)$ & $1(20.0)$ & $4(80.0)$ & $2(40.0)$ \\
\hline Main Campus (5) & $1(20.0)$ & $3(60.0)$ & $1(20.0)$ & $0(0.0)$ & $2(20.0)$ & $1(20.0)$ \\
\hline Pyanku Campus (5) & $1(20.0)$ & $2(40.0)$ & $2(40.0)$ & $1(20.0)$ & $3(60.0)$ & $2(40.0)$ \\
\hline Nasarawa Road (5) & $2(40.0)$ & $3(60.0)$ & $3(60.0)$ & $2(40.0)$ & $3(60.0)$ & $3(60.0)$ \\
\hline Total (25) & $9(36.0)$ & $14(56.0)$ & $10(40.0)$ & $5(20.0)$ & $14(56.0)$ & $10(40.0)$ \\
\hline
\end{tabular}

Key: Pseud.aerug.- Pseudomonas aeruginosa; Staph. aureus- Staphlococcus aureus

Table 5. Isolation rates of the fungal isolates (\%) in the air environment around waste dumpsites in Keffi Metropolis.

\begin{tabular}{|c|c|c|c|c|c|c|c|c|}
\hline Locations (n) & $\begin{array}{l}\text { Asperg. } \\
\text { flavus (\%) }\end{array}$ & $\begin{array}{l}\text { Asperg. } \\
\text { niger }\end{array}$ & $\begin{array}{l}\text { Alternaria } \\
\text { spp. (\%) }\end{array}$ & $\begin{array}{l}\text { Penicillium } \\
\text { spp. (\%) }\end{array}$ & $\begin{array}{l}\text { Mucor spp. } \\
(\%)\end{array}$ & $\begin{array}{l}\text { Fusarium } \\
\text { spp. }(\%)\end{array}$ & $\begin{array}{l}\text { Rhizopus } \\
\text { stolinifer (\%) }\end{array}$ & $\begin{array}{l}\text { Candida } \\
\text { spp. (\%) }\end{array}$ \\
\hline Angwan Lambu (5) & $1(20.0)$ & $1(20.0)$ & $1(20.0)$ & $1(20.0)$ & $1(20.0)$ & $1(20.0)$ & $1(20.0)$ & $2(40.0)$ \\
\hline Main Market (5) & $2(40.0)$ & $2(40.0)$ & $1(20.0)$ & $2(40.0)$ & $2(40.0)$ & $0(0.0)$ & $1(20.0)$ & $2(40.0)$ \\
\hline Main Campus (5) & $1(20.0)$ & $1(20.0)$ & $0(0.0)$ & $1(20.0)$ & $1(20.0)$ & $2(40.0)$ & $0(0.0)$ & $1(20.0)$ \\
\hline Pyanku Campus (5) & $2(40.0)$ & $2(40.0)$ & $1(20.0)$ & $2(40.0)$ & $1(20.0)$ & $1(20.0)$ & $0(0.0)$ & $1(20.0)$ \\
\hline Nasarawa Road (5) & $2(40.0)$ & $3(60.0)$ & $2(40.0)$ & $3(60.0)$ & $2(40.0)$ & $1(20.0)$ & $1(20.0)$ & $2(40.0)$ \\
\hline
\end{tabular}

Key: Asperg. Flavus $=$ Aspergillus flavus, Asperg. niger $=$ Aspergillus niger

Table 6. Antibiotic susceptibility pattern of the bacterial Isolates (\%) against some commonly used antibiotics.

\begin{tabular}{|c|c|c|c|c|c|c|}
\hline Antibiotics & E. $\operatorname{coli}(\mathrm{n}=9)$ & $\begin{array}{l}\text { Pseud. aerug. } \\
(\mathrm{n}=14)\end{array}$ & $\begin{array}{l}\text { Staph. Aureus } \\
(\mathrm{n}=10)\end{array}$ & $\begin{array}{l}\text { Proteus vulgaris } \\
(\mathrm{n}=5)\end{array}$ & $\begin{array}{l}\text { Bacillus spp. } \\
(\mathrm{n}=14)\end{array}$ & $\begin{array}{l}\text { Micrococcus spp. } \\
(\mathrm{n}=10)\end{array}$ \\
\hline Amoxicillin & $0(0.0 \%)$ & $1(7.1 \%)$ & $2(20.0 \%)$ & $2(40.0 \%)$ & $4(28.6 \%)$ & $3(30.0 \%)$ \\
\hline Augmentin & $7(77.8 \%)$ & $10(71.4 \%)$ & $6(60.0 \%)$ & $3(60.0 \%)$ & $8(57.1 \%)$ & $7(70.0 \%)$ \\
\hline Gentamycin & $7(77.8 \%)$ & $9(64.3 \%)$ & $6(60.0 \%)$ & $4(80.0 \%)$ & $9(64.3 \%)$ & $9(90.0 \%)$ \\
\hline Perfloxacin & $2(22.2 \%)$ & $6(42.8 \%)$ & $4(40.0 \%)$ & $4(80.0 \%)$ & $6(42.8 \%)$ & $7(70.0 \%)$ \\
\hline Ofloxacin & $3(33.3 \%)$ & $6(42.8 \%)$ & $4(40.0 \%)$ & $3(60.0 \%)$ & $5(35.7 \%)$ & $2(20.0 \%)$ \\
\hline Septrin & $3(33.3 \%)$ & $4(28.6 \%)$ & $6(60.0 \%)$ & $3(60.0 \%)$ & $4(28.6 \%)$ & $2(20.0 \%)$ \\
\hline Co-trimoxazole & $4(44.4 \%)$ & $8(57.1 \%)$ & $4(60.0 \%)$ & $0(0.0 \%)$ & $4(28.6 \%)$ & $1(10.0 \%)$ \\
\hline Chloramphenicol & $8(88.8 \%)$ & $0(71.4 \%)$ & $6(60.0 \%)$ & $3(60.0 \%)$ & $8(57.1 \%)$ & $5(50.0 \%)$ \\
\hline Sparfloxacin & $5(55.5 \%)$ & $5(35.7 \%)$ & $2(20.0 \%)$ & $2(40.0 \%)$ & $4(28.6 \%)$ & $3(30.0 \%)$ \\
\hline
\end{tabular}

Key: Pseud.aerug. $=$ Pseudomonas aeruginosa, Staph. Aureus $=$ Staphylococcus aureus 


\section{Discussion}

Epidemiological studies have shown that many people around the world are exposed to biological agents [22]. Unfortunately there is no official reference limit for the microbiological quality of air in human environments; notwithstanding the air environment around waste disposal sites harbour several airborne pathogenic microorganisms with serious consequence to humans, animals Also, one of the main aspects of concern is the pollution caused by these dirty environments to the earth - be it land, air and water as observed form literatures. This present study identifies the microbiological quality of the air environment around waste dumpsites and also highlights risk it poses to public health. Consequently, the following microbial isolates were encountered, they include; E. coli, Pseudomonas aeruginosa, Salmonella spp., Staphylococcus aureus, Proteus vulgaris, Bacillus spp., Micrococcus spp., Aspergillus flavus, Aspergillus niger, Alternaria spp., Penicillium spp., Mucor spp., Fusarium spp., Rhizopus stolonifer and Candida spp. A comparative analysis of the results obtained from this study with others conducted by other researchers posed some difficulty due to the small number of available publications and some methodological limitations.

However, several workers have reported similar microorganisms within air environment of both indoor and outdoor air [10, 6, 23, 16]. Pseudomonas aeruginosa, Bacillus spp., Micrococcus spp. and Staphylococcus aureus were the most occurring bacterial species in this present study, while Penicillium spp., Aspergillus niger and Candida spp. were the most encountered fungi species.

The preponderance of these microbial agents conforms to a study conducted by Makut et al. [6] who reported similar agents as the most commonly encountered airborne pathogens. The argument for their conformity apart from observing similar frequent microbial contaminants, also stem from the fact that the respective studies were conducted in a similar setting, the outdoor air environment, only that this present study was around waste disposal sites. Nevertheless, Pseudomonas aeruginosa, Bacillus spp., Micrococcus spp., Fusarium spp., Rhizopus stolonifer and Penicillium spp. are common components of the soil biological communities, and Fusarium spp. and Rhizopus stolonifer been plant pathogens may be an indication of possible farming activities around this ecosystem which perhaps contribute to their high occurrence in addition to human activities regarding waste disposal as described by Udo-Ibiam et al. [16].

Similarly, the presence of the filamentous yeast, Candida spp. which is part of the microbiota of the vagina may be due to the frequent urination around these waste sites and the subsequent activities of scavengers who constantly raises dusts through their scavenging activities. However, members of the Enterobacteriaceae, E. coli, Salmonella spp. and Proteus vulgaris encountered in this study could have emanated from wastewater and faecal matter of both human and animal source deposited around these waste environments which may contaminate the air and even foods sold around these environments. This is in agreement with some work on the distribution and public health implication of enteric pathogens $[24,25,15,7]$.

Specifically, Aspergillus niger and Penicillium spp. with as isolation rate of $36.0 \%$ each is the most isolated fungal contaminants. Interestingly, Mouli et al. [26] reported Aspergillus spp. and Penicillium spp. as the predominant contaminating fungi genera of the air environment in their study. Similarly, Ekhaise et al. [27] also reported Aspergillus spp. as the most common genus of fungi in the air which further reinforces the findings of this present study. Remarkably, these fungi contaminants particularly the Aspergillus spp. and Mucor spp. were pathogenic and had been implicated as the etiological agents of several mycotic infections. High Microbial load were recorded in this present study. The total bacterial counts from the air of these waste dumpsites environments ranged between $22-74 \mathrm{cfu} / \mathrm{m}^{3}$ and 14- $44 \mathrm{cfu} / \mathrm{m}^{3}$ and non is above $10^{3} \mathrm{cfu} / \mathrm{m}^{3}$ which is equal to $1000 \mathrm{cfu} / \mathrm{m}^{3}$ which is not above recommended limits of $10^{3}$ $\mathrm{cfu} / \mathrm{m}^{3}$ suggested by the National Institute of Occupational Safety and Health (NIOSH). In the same vein, the American Conference of Governmental Industrial Hygienists suggested a limit of $500 \mathrm{cfu} / \mathrm{m}^{3}$ of culturable bacteria which was presented to the World Health Organization Experts Meeting in Berlin, Germany as observed by (Makut et al. [6]. Similarly, the total fungal loads did not exceeded the recommended limits of $10^{3} \mathrm{cfu} / \mathrm{m}^{3}$ as threshold limits for fungal concentrations in the air as reported by Gorny and Dutkiewicz [28].

Consequently, in view of some of the established threshold limits for bacteria concentrations in air environment, it is obvious that the air environment around this waste disposal sites is heavily loaded by several genera of microorganisms. Higher loads were recorded for air environment around waste disposal sites in Nasarawa Road, Keffi Main Market and Angwan Lambu neighbourhood. This is expected because these areas usually are characterized by high human activities and vehicular movements, which will contribute to the dissemination of these microbial agents by airborne routes. This is of public health importance in view of the fact that most ready-to-eat food hawkers display their wares in the open, which may be vulnerable to contamination through this means. This has been demonstrated by Obiekezie et al. [25] in their works on the aerobic microbiological contamination of Nono - a locally fermented milk beverage commonly sold in the open by local Fulani women within the same study area.

The antibiotic susceptibility pattern of the bacterial isolates against conventional antibiotics displayed varying degree of susceptibility. The bacterial contaminants were highly susceptible to the following broad spectrum antibiotics, viz; Augmentin, Gentamycin and Chloramphenicol. Their high susceptibility perhaps could be due to the fact that these drugs mostly are administered via the parenteral routes which will limit their misuse and/or abuse which had been reported 
to account for the upsurge in the incidence and preponderance of resistance amongst antibiotics. This conforms to the report of other workers such as those of Ngwai et al. [24], Isibor and Ekundayo [29], Makut et al. [6] and Kabir et al. [23]. There is established evidence that for most bacteria, increased usage of a particular drug correspond with increased incidence and prevalence of bacterial resistance [30]; perhaps this explains the high resistant of the bacterial isolates against the following readily used antibiotics, viz; Amoxicillin and Septrin. These antibiotics are usually administered over the counter by patent medicine store owners without prescription, and Septrin for instance is the most commonly use antibiotics for the treatment of cold and feverish conditions, thereby making them readily accessible and affordable which encourages misuse. This is in conformity with the reports of Obiekezie et al. [15]. Nevertheless, susceptibility of Salmonella spp. to Amoxicillin is surprising because of some recent reports that demonstrate that they consistently exhibited resistance to the drug. This finding is promising since this drug is still the first drug of choice for the treatment of typhoid and parathypoid fever. The variation in susceptibility or resistance pattern of bacteria reported in different geographic locations may be attributable mainly to the usage of those antibiotics for medical, veterinary purpose and also in other fields in that region. Hence, the development of antimicrobial resistance by this bacterium to these drugs poses a major challenge in both human and animal medicine because these drugs are commonly used in the treatment of human ailments and in veterinary practice.

Thus, the presence of bacteria and fungi of public health importance isolated in this study is a cause of concern as described vividly in studies conducted elsewhere, such as those of Mentese et al. [32], Mandal and Brandl [33] and Suleman et al. [34]. Meanwhile, the improper waste disposal method adopted by the populace seems to exacerbate the problem because the waste constitutes a major cause of environmental pollution. Unfortunately, people that conduct their day to day activities within this terrain are exposed to many infections due to the poor quality of the air [31].

\section{Conclusion}

In this study, six genera of bacteria and nine fungi genus were isolated from the air environment around waste disposal sites within Keffi metropolis and were found not to be above recommended limits set by regulatory agencies concerning bioaerosol concentrations. The study therefore revealed that the microbial composition of waste disposal areas potentially have environmental and public health implications. Health risk assessment indicates the presence of pathogenic bacteria and moulds with serious health risk to people within the environment due to the possibility of cross-contamination of foods sold in the open. Epidemiological studies have demonstrated that exposure to these potentially pathogenic microbial agents is of public health consequence. Unfortunately however, there seems not to be quantitative health-based guideline values or thresholds for acceptable levels of microbial contamination in Nigeria. Hence, there is the need for the Nigerian Ministry of Environment and other associated regulatory bodies to establish such thresholds for Nigeria which will guide policies regarding the microbiological quality of air environment for better health.

\section{Recommendations}

From the findings of this study, the following recommendations became necessary, they include;

i. To mitigate the effect of pathogenic airborne microorganism around environment inhabited by humans, there is the need to ensure that refuse are dumped far away from residential settings so as to reduce the chance of exposure to these bioaerosols

ii. Liquid wastes should be properly treated before their subsequent release and should be channeled through the sewers in view of the hazard they pose to the environment.

iii. Foods should not be exposed around waste dumpsite environment because of the risk of cross-contamination to humans.

iv. Finally, there is the need to periodically monitor the number of microorganisms within the air of waste dumpsite environments using the established threshold stipulated for microbial concentrations in air.

\section{References}

[1] Uzoigwe, C. I. and Agwa, O. K. (2012). Microbiological quality of water collected from boreholes sited near refuse dumpsites in Port Harcourt, Nigeria. African Journal of Biotechnology. 11 (13): 3135-3139.

[2] Bassey, I. U., Brooks, A. A., Asikong, B. E. and Andy, I. E. (2015). Environmental and Public Health Aspects of Solid Waste Management at the Lemna Dumpsite in Calabar, Cross River State, Nigeria. International Journal of Tropical Disease and Health. 10 (3): 1-13.

[3] Recer, G., Browne, M., Horn, E., Hill, K. and Boehler, W. (2001). Ambient air levels of Aspergillus funigatus and Thermophilic actinomycetes in a residential neighbourhood near a yard-waste composting facility. Aerobiologia. 17: 99106.

[4] Adhikari, A., Reponen, T., Lee, S. and Grinshpun, S. (2004). Assessment of human exposure to airborne sampling. Annals of Agricultural and Environmental Medicine. 11: 269-277.

[5] Gillum, S. and Leventin, E. (2008). The air spora close to a compost facility in Northeat Oklahoma, part 1: spore trap sampling. Aerobiologia. 24: 3-12.

[6] Makut, M. D., Nyam, M. A., Shehu, L. and Anzaku, S. J. (2014). A survey of the microflora of the outdoor air environment of Keffi metropolis, Nasarawa State, Nigeria. African Journal of Microbiology Research. 8 (27): 26502655. 
[7] Fowoyo, P. T. and Igbokwe, O. E. (2014). Impact of Air Pollution on the Microbiological Quality of Ready to Eat Hawked Foods Sold around a Cement Factory in Lokoja, Nigeria. American Journal of Research Communication. 2 (11): 138-157.

[8] Rylander, R. (2004). Microbial cell wall agents and sick building syndrome. Advances in Applied Microbiology. 55: $139-154$.

[9] Guo, H. (2011). Source apportionment of Volatile organic compounds in Hong Kong homes. Building and Environment. 46 (11): $2280-2286$.

[10] Khan, A. A. H. and Karuppayil, S. M. (2012). Fungal pollution of indoor environments and its management. Saudi Journal of Biological Sciences. 19: 405-426.

[11] Medrela-Kuder, E. (2002). Seasonal variations in the occurrence of culturable airborne fungi in outdoor air in Cracow. International Biodeterioriation and Biodegradation. 52: 203-205.

[12] Nwanta, J. A. and Ezenduka, E. (2010). Analysis of Nsukka Metropolitan Abattoir Solid Waste in South Eastern Nigeria: Public Health Implications. Archives of Environmental and Occupational Health. 65 (1): 21-26.

[13] Nabegu, A. B. (2010). An Analysis of Municipal Solid Waste in Kano Metropolis. Journal of Human Ecology. 31 (2): 111119 .

[14] Sankoh, F. P., Yan, X. and Tran, Q. (2013). Environmental and Health Impact of Solid Waste Disposal in Developing Cities: A Case Study of Granville Brook Dumpsite, Freetown, Sierra Leone. Journal of Environmental Protection. 4: 665-670.

[15] Obiekezie, S. O., Ndimele, E. C. and Otti, T. A. (2013). Antibiotic Resistance Pattern of Bacteria Species Isolated From Wastewater in Bingham University Clinic, Karu, Nasarawa State, Nigeria. Int. J. Biotechnol. and Allied Sci. 8 (1): $1070-1076$.

[16] Udu-Ibiam, O. E., Maduka, A. V., Samuel, C. O., Oluwatoyin, O. O., Orji, J. O. and Elsie Ekeghalu, C. (2016). Microbiological Analysis of Outdoor Air Quality of Male and Female Hostels in Ebonyi State University, Abakaliki, Ebonyi State, Nigeria. Journal of Pharmacy and Biological Sciences. 11 (3): 68-73.

[17] Kalwasinska, A., Burkowska, A. and Wilk, I. (2012). Microbial contamination in indoor environment of university library. Annals in Agricultural and Environmental Medicine. 19 (1): 25-29.

[18] Stryjakowska-Sekulska, M., Piotraszewska-Pająk, A., Szyszka, A., Nowicki, M. and Filipiak, M. (2007). Microbiological quality of indoor air in university rooms. Polish Journal for Environmental Study. 16 (4): 623-632.

[19] Holt, J. G. (1994). Bergey's manual of determinative bacteriology, $9^{\text {th }}$ edition, Lipincott, Williams and Wilkins Co., Baltimore, USA. Pp. 787.

[20] Cheesbrough, M. (2000). District Laboratory Practice in Tropical Countries Part 2, Cambridge University Press, Low Price Edition, pp. 62-69.

[21] CLSI (2009). Performance standards for antimicrobial susceptibility testing: Nineteenth informational supplement.
M100-S19. Clinical and Laboratory Standards Institute, Wayne, Chicago, USA. Pp. 51.

[22] Dales, R., Cakmak, S., Judek, S., Dann, T., Coates, F., Brook, J. and Burnett, R. (2004). Influence of outdoor aeroallergens on hospitalization on asthma in Canada. Journal of Allergy in Clinical Immunology. 113: 303-306.

[23] Kabir, S., Mridha, F., Islam, S. and Shorifujjaman, M. (2016). Microbiological pollutants in air and antibiotic resistance profile of some bacterial isolates. Jahangirnagar University Journal of Biological Sciences. 5 (1): 47-56.

[24] Ngwai, Y. B., Akpotu, M. O., Obidake, R. E., Sounyo, A. A., Onanuga, A. and Origbo, S. O. (2010). Antimicrobial susceptibility of Escherichia coli and other coliforms isolated from urine of asymptomatic students in Bayelsa State, Nigeria. African Journal of Microbiology Research. 5 (3): 184-191.

[25] Obiekezie, S. O., Odu, N. N. and Ogwu, D. (2012). Aerobic Microbiological Quality of Nono sold in Keffi Metropolis. International Journal of Chemical Sciences. 5 (2): 157-162.

[26] Mouli, P. C., Mohan, S. V. and Reddy, S. J. (2005). Assessment of Microbial (Bacteria) Concentrations of Ambient Air at Semi-Arid Urban Region: Influence of Meteorological Factors. Applied Ecology and Environmental Research. 3 (2): 139-149.

[27] Ekhaise, F. O., Ighosewe, O. U. and Ajakpovi, O. D. (2008). Hospital indoor airborne microflora in private and government owned hospitals in Benin City, Nigeria. World Journal of Medical Sciences. 3 (1): 19-23.

[28] Gorny, R. L. and Dutkiewicz, J. (2002). Bacterial and fungal aerosols in indoor environment in Central and Eastern Countries. Annals in Agriculture, Environment and Medicine. 9: $17-23$.

[29] Isibor, J. O. and Ekundayo, A. O. (2012). Determination of the Antibiotic Susceptibility Patterns of Local Isolates of E. coli O157:H7 from Edo State, Nigeria. New York Science Journal. 5 (10): 151-157.

[30] Granizo, J. J., Aguilar, L., Casal, J., Dal-Re, R. and Baquero, F. (2000). Streptococcus pyrogenes resistance to erythromycin in relation to macrolide consumption in Spain (1986-1997). $J$. Antimicrob. Chemother. 46: 959-964.

[31] Occupational Safety and Health Administration (OSHA) (2008). Indoor air quality investigation. Technical Manual (OTM), Sect. II, chapter 2, 2008. [online www.osha.gov/dts/osta/otm/otm_iii//otm_iii_2.ht-ml\#text5].

[32] Mentese, S., Arisoy, M., Rad, A. Y. and Gullu, G. (2009). Bacteria and fungi levels in various indoor and outdoor environments in Ankara, Turkey. Clean. 37: 487-93.

[33] Mandal, J. and Brandl, H. (2011). Bioaerosols in Indoor Environment - A Review with Special Reference to Residential and Occupational Locations. The Open Environmental and Biological Monitoring Journal. 4: 83-96.

[34] Suleman, Y., Darko, E. T. and Agyemang-Duah, W. (2015). Solid Waste Disposal and Community Health Implications in Ghana: Evidence from Sawaba, Asokore Mampong Municipal Assembly. Journal of Civil Environmental Engineering. 5: 202. 